\author{
Kamil Durajczyk \\ Wydział Studiów Międzynarodowych i Politologicznych \\ Uniwersytet Łódzki \\ kamildurajczyk@wp.pl
}

\title{
Hejterstwo w polityce - znak czasów czy odwieczny element gry politycznej?
}

Obecnie między innymi za sprawą rozwoju technologicznego zjawisko hejtu staje się coraz bardziej wszechobecne, a zrozumienie go - jak się wydaje - stanowi klucz do zgłębienia nie tyle wycinka rzeczywistości, co całej epoki współczesnej. Pomimo tak doniosłego znaczenia wciąż zaskakiwać może niewielka liczba badań naukowych poświęconych fenomenowi hejtu, jak i jego konkretnym podrodzajom, które jesteśmy w stanie wyodrębnić. Jednym z tych „gatunków” jest hejt polityczny, który będzie przedmiotem niniejszego artykułu. Punktem wyjścia do moich rozważań chciałbym uczynić pytanie zawarte w tytule tekstu, mianowicie wątpliwość, czy hejterstwo polityczne jest tendencją współczesną czy też stałym komponentem aktywności w obrębie „świata polityki”.

Jak się okazuje, w obliczu niewielkiej ilości źródeł naukowych odnoszących się do zjawiska hejtu problematyczny staje się już sam termin. Póki co nie istnieje bowiem jedno powszechnie uznawane określenie dla desygnatu stanowiącego przedmiot uwagi w niniejszej pracy. W efekcie mamy do czynienia z pewną dowolnością terminologiczną wśród której wyróżnić można nazwy takie, jak: „mowa nienawiści” (Tkaczewski 2010: 181), „mowa wrogości” (To oni sq wszystkiemu winni... Język wrogości w polskim dyskursie publicznym 2013: 117), „retoryka nienawiści” 
(Głowiński 2009: 236) oraz szczególnie modne w kręgach medialnych oraz młodzieżowych anglicyzmy: „hejt” oraz jego pochodne, czyli „hejterstwo" oraz „hejting” (Wawrzyniak 2015: 34-36). Z racji ograniczenia formy artykułu wstrzymuję się od przedstawiania własnych propozycji odnośnie do nazewnictwa, aczkolwiek w dalszej części pracy będę operował przede wszystkim ostatnimi trzema przytoczonymi wyrazami, które w wywodzie takim jak ten jawią się jako najbardziej praktyczne.

$\mathrm{O}$ wiele istotniejsza od kwestii spójnej terminologii — która wykrystalizuje się z biegiem dalszych badań - wydaje się spójność semantyczna oraz definicyjna. Warto w tym miejscu powołać się na kilka propozycji definicyjnych omawianego zjawiska. Monika Nowicka ujmuje hejt jako: „specyficzną formę komunikacji, kładącą szczególny nacisk na negatywne, arbitralnie przypisane cechy przeciwnika, które mimo swojej zewnętrzności są traktowane przez aktorów je nadających jako cechy przyrodzone" (To oni sq wszystkiemu winni... 2013: 117), co jest spojrzeniem dość szerokim, a zarazem ciekawym. Podkreśla się bowiem pewną manipulację zawartą $\mathrm{w}$ hejtowaniu, która polega na wyolbrzymianiu negatywnych cech drugiej strony $\mathrm{w}$ trakcie komunikacji $\mathrm{z}$ nią. $\mathrm{W}$ podobnym tonie utrzymana jest definicja Dariusza Tkaczewskiego, który określa hejt jako:

specyficzny typ dyskursu publicznego, polegający na negatywnym charakteryzowaniu i przypisywaniu niekorzystnych cech i ocen, a w dalszej konsekwencji także nawoływaniu do działań dyskryminujących skierowanych wobec określonych osób, kategorii czy grup społecznych, do których przynależność uwarunkowana jest naturalnie, a nie z wyboru. (Tkaczewski 2010: 181)

W tym przypadku zwraca uwagę podkreślenie, iż aktywność hejterska może nie ograniczać się wyłącznie do retoryki, ale również przekładać się na warstwę behawioralną. Marek Czyżewski z kolei określa mowę nienawiści jako „wypowiedzi lżące, wyszydzające lub poniżające jednostki lub grupy” (Język IV Rzeczypospolitej 2010: 49), zaznaczając przy tym, iż charakterystyczną cechą tego rodzaju retoryki jest przypisywanie cech grupy danej jednostce, co oznacza, że zawsze - pośrednio lub bezpośrednio - odnosi się ona do zbiorowości. Daje się zauważyć pewna zgodność wśród cytowanych autorów, odnajdują oni bowiem następujące wspólne cechy hejtu: przejawianie się tego zjawiska w warstwie retorycznej oraz operowanie w jego ramach negatywnymi cechami adresata komunikatu.

Na potrzeby niniejszego artykułu przyjmę jednak jeszcze inną definicję, która jest zbliżona do powyższych, a zarazem stanowi moją propozycję interpretacji semantycznej terminu hejt. Mianowicie określam to zjawisko jako ws zelką retoryczną aktywność nastawioną na agresywne podkreślanie negatywnych cech danej jednostki lub grupy, która ponadto 
nie posiada cech krytyki, a więc nie jest konstruktywna i nie odnosi się wyłącznie do cech zależnych od danej jednostki lub grupy.

Przejdę teraz do omówienia zjawiska wyrastającego z hejtingu, tzn. hejtu politycznego. Taki hejt funkcjonujący w dziedzinie polityki Michał Głowiński definiuje jako:

(...) retorykę nasyconą agresją (...), której środkami posługują się osoby rozmaicie uplasowane w przestrzeni publicznej, w pewnych sytuacjach jest ona tożsama $\mathrm{z}$ językiem władzy i jej akolitów, sięgają po nią polityczni przywódcy, zajmujący najważniejsze stanowiska w państwie, działacze mniej lub bardziej poważnych organizacji, ale też zawodowi propagandyści i dziennikarze zajmujący się komentowaniem bieżących wydarzeń. Jako przedmiot nienawiści traktowany może być każdy, kogo uważa się za wroga, którego należy zniszczyć. (Głowiński 2009: 236)

Interesujący punkt widzenia na hejt polityczny prezentuje również Irena Kamińska-Szmaj, która utożsamia to zjawisko z terminem „inwektywa polityczna” i definiuje jako: „celowe zachowanie słowne, mające charakter publiczny i dotyczące uczestników życia politycznego, wyrażające negatywne emocje nadawcy względem osoby, grupy osób bądź instytucji, ideologii” (Kamińska-Szmaj 2007: 57).

Z racji skromnej liczby źródeł mogących służyć za pomoc naukową przy pogłębianiu wiedzy o zjawisku hejtu politycznego pozwolę sobie na zaprezentowanie własnej propozycji definicyjnej. W moim rozumieniu jest to posługiwanie się hejtem w obrębie życia politycznego, zarówno przez aktywnych jak i biernych jego uczestników (obserwatorów i komentatorów). Wyraźnie daje się więc wyodrębnić dwa rodzaje partycypowania w hejcie politycznym. Pierwszym, który określiłbym jako c zyn ny (z racji dwuznaczności słowa „aktywny” w tym kontekście), operują przede wszystkim politycy - korzystają z niego zarówno względem innych osób aktywnie działających w „świecie polityki”, jak i często wobec osób niezaangażowanych w tę sferę życia. Z kolei hejt polityczny bi e r ny charakterystyczny jest dla tej drugiej grupy ludzi (a więc nie-polityków) i analogicznie może być stosowany zarówno względem przedstawicieli tejże grupy, jak i wobec polityków. Widać więc, że wyróżnikiem takiej typologizacji jest podmiot operujący hejtem i to na niego należy przede wszystkim zwracać uwagę, chcąc przyporządkować dany hejt do określonej grupy. Rozróżnienie to będzie podstawą moich dalszych rozważań.

Choć mój artykuł nie ma charakteru typowo eksplanacyjnego, a stanowi bardziej przyczynek do dalszych rozważań nad zagadnieniem hejtu politycznego, nie może się on obyć bez próby wskazania przyczyn omawianego zjawiska. Kończąc 
rozważania teoretyczne, posłużę się więc ustaleniami Kamińskiej-Szmaj odnośnie do źródeł hejtu w interesującej mnie warstwie rzeczywistości, jaką jest szeroko rozumiana polityka. Badaczka wskazuje na następujące źródła mowy nienawiści: ideologie w których zawarta jest niechęć wobec obcych, innych ludzi, ideologie związane ściśle z przemianami rewolucyjnymi, które w agresji i przemocy upatrują podstawowego sposobu walki z wrogiem, przyjęta strategia komunikacyjna bazująca na budowaniu wizerunku silnego polityka, bezkompromisowo rozprawiającego się z wrogami (a więc pośrednio po prostu doraźne cele polityczne), oraz podstawa biologiczna tj. instynktowne zachowania mające umocnić pozycję przewodzącą danej jednostki w „stadzie” (Kamińska-Szmaj 2007: 53-54). Jak widać, przyczyny te odnoszą się przede wszystkim do hejterstwa politycznego czynnego; biorąc pod uwagę dokonany powyżej podział, dodałbym do tej grupy także pobudki charakterystyczne dla biernej odmiany hejtu politycznego. Mam tu na myśli dodatkową przyczynę biologiczną, a więc pokłady agresji obecne w każdym człowieku, które uzewnętrzniają się np. w trakcie kontaktu, via środki masowego przekazu z nielubianym politykiem. Ponadto należałoby wyróżnić stosowanie hejtu jako formy kompensacji niepowodzeń i frustracji życiowych (co po części wiąże się z poprzednim czynnikiem) i wreszcie hejt wynikający z poczucia anonimowości w przestrzeni wirtualnej, które wyzwala nieuświadamiane często pokłady nienawiści względem innych, $\mathrm{w}$ tym $\mathrm{m}$.in. polityków, co z kolei bierze się z (fałszywego) przeświadczenia o totalnej bezkarności panującej w internecie.

Przystąpię teraz do dokładniejszego omówienia hejterstwa politycznego biernego. Można domniemywać, iż zjawisko to obecne było od zawsze, choćby w relacjach prywatnych ludzi w każdej z epok, co oczywiście - z racji braku materiału empirycznego - musi pozostać w gronie przypuszczeń. Współcześnie wyodrębnienie i wskazanie przykładów tego typu hejterstwa jest możliwe przede wszystkim za sprawą internetu i zawartych w nim treści. Sekcje z komentarzami internautów pod większością artykułów dotyczących polityki bądź polityków momentalnie wypełniają się hejtami umieszczanymi najczęściej z anonimowych kont. Dzieje się tak niezależnie od orientacji politycznej danego portalu (o ile takową da się określić). Najczęściej hejty przepełnione są wulgaryzmami, jednak zdarzają się także przypadki względnie łagodniejsze ${ }^{1}$.

1 Warto posłużyć się w tym miejscu przykładami (wybranymi spośród grona względnie łagodniejszych hejtów). Zachowana pisownia oryginalna.

Portal niezależna.pl - komentarz pod artykułem Zobacz, zanim zablokuja! WIDEO „Wszystkie twarze Ewy Kopacz” podbija internet: „kopacz to pacynka tuska, Tusk jest sprawcą tego całego zła które doświadczamy w Polsce. Kopacz była za słaba na te mafijne ustawki, nie dała rady. Tuska trzeba ściągnąć do Polski i tu go odpowiednio potraktować przed sądem”. [źródło: http://niezalezna.pl/72035zobacz-zanim-zablokuja-wideo-wszystkie-twarze-ewy-kopacz-podbija-internet dostęp: 08.02.2016]. 
Bardzo często hejterstwo polityczne bierne bazuje na ksenofobii, szowinizmie, rasizmie i innych tego typu patologiach społecznych. Odpowiednim przykładem jest reakcja internetu na napływ uchodźców z ogarniętej wojną domową Syrii oraz innych krajów Bliskiego Wschodu i Afryki, którego pierwsza kulminacja stała się faktem w 2015 roku. Sprawa ta — poza społecznym - ma również oczywisty wymiar polityczny i przedstawiana jest jako jeden z największych kryzysów geopolitycznych Unii Europejskiej od lat czy nawet w całej jej historii (Kryzys migracyjny w UE, największy od II wojny światowej 2015). Zarazem hejty polskich internautów pod artykułami dotyczącymi tego wydarzenia nie są adresowane do polityków (choć również), ale przede wszystkim wymierzone są w samych uchodźców² .

Nowym i dopiero wykształcającym się zjawiskiem jest hejt internetowy realizowany na zamówienie. Oznacza to, iż mamy do czynienia nie $\mathrm{z}$ hejtem stanowiącym uzewnętrznienie faktycznych emocji autora danej treści, lecz z hejtem realizowanym w celach zarobkowych, ekonomicznych. Przestrzenią świetnie przystosowaną do realizacji tego rodzaju hejterstwa jest czas kampanii wyborczych, który charakteryzuje się określoną dynamiką i koniecznością szybkich reakcji w przestrzeni wirtualnej. Wedle niepotwierdzonych, acz powtarzających się wielokrotnie w mediach informacji, $\mathrm{z}$ usług tego rodzaju hejtu na zamówienie miały korzystać główne sztaby wyborcze w czasie kampanii przed wyborami prezydenckimi w maju 2015 roku. Tym wydarzeniom pozostającym w sferze przypuszczeń poświęcone zostało wiele treści medialnych, m.in. prasowych („Newsweek” nr 6/2016: 10-14), telewizyjnych (program Czarno na białym w TVN24) oraz internetowych (Wiśniewska 2015). Jednakże przedstawiciele dwóch głównych

Portal onet.pl - komentarz pod artykułem Jarosław Kaczyński uhonorowany tytułem Człowieka Roku „Wprost” 2015: „Nagroda jak najbardziej Kaczyńskiemu się należy. Będąc zerem, przez wiele lat żyjąc za pieniądze podatników, będąc największym życiowym nieudacznikiem ze wszystkich polityków, w przeciągu roku karmiąc Polaków kłamstwem nazywanym Dobrą Zmianą, zdobył wszystko. Został Naczelnikiem Polski". [źródło: http://wiadomosci.onet.pl/kraj/czlowiek-roku-wprost-2015jaroslaw-kaczynski-uhonorowany/hqs46r dostęp: 08.02.2016].

2 W tym wypadku również zdecydowana większość hejterskich komentarzy ma charakter wulgarny. Poniżej kilka stosunkowo najłagodniejszych przykładów. Zachowana pisownia oryginalna.

Portal wprost.pl - komentarz pod artykułem Imigranci wdzieraja się do domów. „Są bezkarni”: „W Polsce będzie to samo, jeżeli nie będziemy na tyle zapobiegliwi i nie zablokujemy importu tego robactwa" [źródło: http://www.wprost.pl/ar/530713/Imigranci-wdzieraja-sie-do-domow-Sa-bezkarni/ dostęp: 08.02.2016].

Portal wpolityce.pl - komentarz pod artykułem Pierwszy region $w$ Polsce ma problem $z$ uchodźcami. „Zaczepiaja mieszkańców”. Wprowadzono specjalne patrole: „zbierać sie w grupy i prac popaprańców niech wiedzą że Polak to nie niemiec i tu nie wolno im się panoszyć" [źródło: http:// wpolityce.pl/spoleczenstwo/280410-pierwszy-region-w-polsce-ma-problem-z-uchodzcamizaczepiaja-mieszkancow-wprowadzono-specjalne-patrole dostęp: 08.02.2016]. 
ugrupowań politycznych oskarżanych o tego typu praktykę konsekwentnie dementowali te doniesienia ${ }^{3}$.

Co ważne, polityczne hejterstwo bierne nie uobecnia się jedynie w przestrzeni internetowej oraz $\mathrm{w}$ relacjach prywatnych członków ogółu społeczeństwa. Polem jego odziaływania są również środki masowego przekazu, a podmiotami dziennikarze, publicyści czy wszelkiej maści medialni komentatorzy wydarzeń politycznych. Aby jednak pozostać wiernym dokonanej uprzednio typologizacji, należy zaznaczyć pewną kontrowersyjność tej części omawianego zjawiska. Należy bowiem pamiętać, iż wiele środowisk medialnych umocowanych jest ściśle w określonej orientacji politycznej i powiązanych (formalnie lub nieformalnie) $\mathrm{z}$ danymi formacjami politycznymi. Stawia to pod znakiem zapytania proweniencję konkretnych hejtów, a mianowicie to, czy wywodzą się one z autonomicznego namysłu autora, czy też są wpisane w pewien model konfrontacji politycznej, w której twórca hejtu niemal jawnie opowiada się po jednej ze stron i wszelkie kreowane przez siebie treści dopasowuje do popieranej opcji politycznej. Niestety, w większości przypadków niezwykle trudno w sposób jednoznaczny wykazać tego typu powiązania i zależności (wyjątkiem są tu oficjalne organa prasowe partii politycznych, które przyporządkować można do hejtu czynnego, gdyż pośrednio wyrażają opinie i poglądy polityków). Toteż pozostaje utrzymać równoważność pomiędzy wszelkimi typami biernego hejterstwa politycznego, oddając potencjalnym przyszłym badaczom tego zjawiska pod rozwagę kwestię faktycznych przesłanek kryjących się za każdym konkretnym przypadkiem hejterstwa medialnego.

Aby nie ograniczyć się do retoryki stricte deklaratywnej, przytoczę kilka przykładów hejtu biernego zawartego w publikacjach prasowych. Na gruncie polskim hejterstwo medialne szczególnie widoczne było w okresie międzywojennym, kiedy to łamy prasy stanowiły jeden z głównych obszarów rywalizacji politycznej w kraju. Zapewne wynikało to $\mathrm{z}$ faktu, iż ówcześnie prasa była podstawowym środkiem masowego przekazu, który obejmował swym zasięgiem de facto całe społeczeństwo, a co za tym idzie stanowił bardzo ważne pole konfrontacji politycznej. W ramach konfrontacji tej nierzadko odwoływano się do hejtu, w czym prym wiodły przede wszystkim organa prasowe konkretnych sił politycznych, stanowiące znaczną część

3 Podmiotami dementującymi byli: z ramienia Prawa i Sprawiedliwości sekretarz stanu w Kancelarii Prezesa Rady Ministrów, Paweł Szefernaker [źródło: http://www.dziennikzachodni. pl/artykul/9268243,szefernaker-pis-nie-zatrudnia-hejterow-wygralismy-pozytywnym-przekazemchcemy-to-kontynuowac,id,t.html dostęp: 08.02.2016] i w przypadku Platformy Obywatelskiej ówczesna rzeczniczka rządu Ewy Kopacz, Małgorzata Kidawa-Błońska [źródło: http://wiadomosci.onet.pl/ kraj/rzeczpospolita-po-zatrudnila-internetowychInternetowych-hejterow/3g9k4r dostęp: 08.02.2016]. 
polskiego rynku prasowego tamtych lat ${ }^{4}$. Współczesne polskie media nie obfitują w praktyki hejterskie, co być może ma związek z poczuciem odpowiedzialności za słowo. To z kolei wiąże się z potężnym zasięgiem największych polskich nadawców treści medialnych, a być może po prostu $\mathrm{z}$ odpowiednim doborem (profesjonalnych) kadr do tychże ośrodków. Jednakże przypadki hejtu zdarzają się w mediach pomniejszych, najczęściej reprezentujących skrajne opcje ideowo-polityczne. I tak w lewicowej „Trybunie” napotkać można określenia takie, jak: „cham z warchołem”, „hołota”, „idiota”, „kreatury”, „kretyni”, „mały człowieczek, który zamieszkuje Pałac Prezydencki” zaś w prawicowej „Gazecie Polskiej”: „baran”, „hieny” oraz „przygłup” (To oni sa wszystkiemu winni... 2013: 149-170).

Drugą kategorią hejtu w polityce jest hejt czynny, a więc hejting stosowany przez polityków. Przedmiotem mojego zainteresowania w tej części artykułu są jednak przede wszystkim wypowiedzi publiczne, nie zaś retoryka nienawiści wyartykułowana w sytuacjach prywatnych (co nie oznacza, iż te drugie nie kwalifikują się do kategorii hejtu czynnego, gdyż - co należy z całą mocą ponownie podkreślić - przy tym wyróżnieniu pryncypalnym elementem jest nadawca hejtu, nie zaś adresat czy okoliczności wypowiedzi). Materiały źródłowe dla takich zachowań są dość obszerne i sięgają aż starożytności. Hejtem posługiwał się choćby jeden z najsłynniejszych mówców greckich Demostenes, który swoich przeciwników obrzucał obelgami typu: „pospolity błazen”, „zdrajca”, „sprzedawczyk”, „szmaciarz” czy „skończony łotr” (Kamińska-Szmaj 2007: 47). Można więc domniemywać, że skoro na tego typu epitety pozwalała sobie postać pokroju Demostenesa, to nie były one obce innym politykom antycznej Hellady, o których historia — być może więc i słusznie - zapomniała.

Czynny hejt polityczny nieobcy był również realiom tzw. Rzeczpospolitej szlacheckiej. Retoryka sejmowa i sejmikowa szlachty polskiej obfitowała w ataki werbalne, które dziś określilibyśmy jako hejt. Uobecniła się wówczas także cała odrębna gałąź twórczości literackiej — pamflety — jak również pospolite paszkwile, tworzone w reakcji na bieżące wydarzenia polityczne, religijne i społeczne, nierzadko przez czynnych polityków, którzy w ten sposób bez pardonu atakowali przeciwników politycznych. Często motywy takich zachowań były najniższe z możliwych, bowiem ogniskowały się wokół rywalizacji o stanowiska polityczne (Kamińska-Szmaj 2007: 48-49).

4 Zgodnie z przyjętym obwarowaniem nie będę przytaczał w tym miejscu konkretnych przykładów - jako niewpisujących się w koncept hejterstwa politycznego biernego - polecam jednak pracę na ten temat Ireny Kamińskiej-Szmaj: Judzi, zohydza, ze czci odziera. Język propagandy politycznej w prasie 1919-1923 (Wrocław 1994). 
W historii natrafić można na postacie szczególnie „hejterskie”, a więc takie, które specjalizują się w posługiwaniu tego typu retoryką. Co ciekawe, zdarzają się wśród nich również osoby uważane za wybitne w danej dziedzinie i nierzadko legendarne w obrębie danej kultury. Przykładem łączącym oba typy jest Józef Piłsudski - dla narodu polskiego mąż opatrznościowy, który zakończył mroczny okres zaborczej likwidacji państwowości. Z interesującego nas punktu widzenia Piłsudski jawi się jednak przede wszystkim jako „zasłużony” hejter po wielokroć operujący tą techniką retoryczną w swojej politycznej karierze. Warto w tym miejscu przytoczyć wypowiedzi i określenia, jakie padały z jego ust w stosunku przede wszystkim do innych polityków: „bałwan”, „idiota”, „bubek”, „dureń” czy „ścierwo” (Kamińska-Szmaj 2007: 96-262).

W hejterstwie wyspecjalizowała się również propaganda władz komunistycznych okresu Polskiej Ludowej. Najsłynniejsze bodaj akty hejterstwa w jej wykonaniu to atakowanie uczestników wystąpień robotniczych i opozycyjnych - począwszy od marca 1968 roku - stałym zespołem inwektyw, wśród których wyróżnić należy choćby „wichrzycieli” (Kamińska-Szmaj 2007: 277-278) i — „awanturników” (Kamińska-Szmaj 2007: 94). Charakterystyczny jest także wywodzący się z plakatów propagandowych z lat czterdziestych slogan „zaplute karły reakcji” skierowany wobec żołnierzy Armii Krajowej i innych organizacji niepodległościowych ${ }^{5}$ (Kamińska-Szmaj 2007: 288). Po hejterską metodę retoryczną sięgali również sami przedstawiciele ówczesnych elit politycznych. Przykładowo Bolesław Bierut siły opozycyjne względem wyznawanej przez siebie ideologii politycznej określał mianem „bandy zdrajców, szpiegów i dywersantów”, Władysław Gomułka przyrównywał postawę etyczną poety Janusza Szpotańskiego do „moralności alfonsa”, a jego utwór określał mianem „reakcyjnego paszkwilu, ziejącego sadystycznym jadem nienawiści do (...) partii” (Kamińska-Szmaj 2007: 97-120). Niewątpliwie jednak najsłynniejszym przykładem mowy nienawiści autorstwa przedstawiciela władz państwowych PRL jest wypowiedź premiera Józefa Cyrankiewicza, który w reakcji na wydarzenia tzw. „poznańskiego czerwca” roku 1956 stwierdził:

5 Ciekawe i warte odnotowania jest, iż zwrotu „zapluty karzel” jako pierwszy użył Józef Piłsudski, padło ono podczas jednego z publicznych wystąpień marszałka w latach dwudziestych XX wieku. Nie wiadomo jednak, czy to właśnie ta wypowiedź stanowiła inspirację dla komunistycznej propagandy - co dowodziłoby interesującej prawidłowości inspiracji hejterskiej niebaczącej na różnice światopoglądowo-ideologiczne - czy też może zaszła tu przypadkowa zbieżność. Nie można również wykluczyć wariantu inspiracji nieświadomej. 
Każdy prowokator czy szaleniec, który odważy się podnieść rękę przeciw władzy ludowej, niech będzie pewny, że mu tę rękę władza ludowa odrąbie, w interesie klasy robotniczej, w interesie chłopstwa pracującego i inteligencji, w interesie walki o podwyższenie stopy życiowej ludności, w interesie dalszej demokratyzacji naszego życia, w interesie naszej Ojczyzny. (Faryś 1998: 37)

W hejt obfituje polityka współczesna - na gruncie polskim wyróżnia się $\mathrm{w}$ tej dziedzinie kilka postaci, na szczególną uwagę zasługują zwłaszcza polityk Platformy Obywatelskiej Stefan Niesiołowski oraz Krystyna Pawłowicz z Prawa i Sprawiedliwości, których liczne jawnie hejterskie wypowiedzi ubarwiają przekaz medialnych od wielu lat. To właśnie obecność i swojego rodzaju nadreprezentatywność mowy nienawiści w mediach wpływa na jej upowszechnianie i rosnącą popularność takiej formy wyrazu. Wynika to $\mathrm{z}$ „marketyzacji” sfery polityki, a więc tendencji, której jesteśmy świadkami na gruncie polskim de facto od powstania obecnego modelu państwowego, jakim jest III Rzeczpospolita. Owa tendencja wymusza na ośrodkach medialnych stawianie na treści rentowne, a więc takie, które znajdą szerokie grono zainteresowanych odbiorców, co niekoniecznie idzie w parze z posiadaną przez nie wartością. Przykładem jest tu właśnie mowa nienawiści, która spotyka się z potężną recepcją ze strony społeczeństwa. $\mathrm{W}$ ten sposób niejednokrotnie generuje ona dla ośrodków medialnych zyski, wynikające z oferty reklamodawców gotowych wykupić miejsce lub czas antenowy dla reklamy swojego produktu w dogodnym - a więc popularnym - obszarze prezentacji medialnej. Warto przytoczyć tu wypowiedź premiera Leszka Millera do posła Zbigniewa Ziobry podczas przesłuchania tego pierwszego przed komisją do spraw tzw. afery Rywina. Prezes Rady Ministrów zwrócił się wtedy do parlamentarzysty słowami: „Pan jest zerem, panie pośle” (Lis 2006: 82). Biorąc pod uwagę wszelkie standardy interakcji społecznej czy kultury osobistej, wypowiedź taka powinna zostać uznana za wysoce niewłaściwą, a nawet $-\mathrm{z}$ pogardy dla tej formy - przemilczana. W rzeczywistości medialnej polskiej polityki początków XXI wieku słowa te jednak szybko zostały spopularyzowane, a wielokrotne ich powielanie w przekazach medialnych spowodowało, iż uzyskały one status niemal kultowego cytatu polskiej polityki. Choć - jak wypada wierzyć - te słowa mogły zostać spopularyzowane również z pobudek „dydaktycznych”: chęci późniejszego ukarania premiera poprzez werdykt wyborczy. W rzeczywistości efekt ich rozpowszechniania był odwrotny i można zaryzykować tezę, że stanowiły one zachętę do dalszego potęgowania napięcia politycznego, a co za tym idzie korzystania z praktyk hejterskich (co zresztą w kolejnych latach nastąpiło). Każe to postawić pytania o ocenę moralną jakości polskiej polityki po 1989 roku, która w sposób ewidentny pogrąża się w postępującym procesie „hejteryzacji”. 
Rozważania rozpocząłem od postawienia pytania o obecność zjawiska hejtu w polityce na przestrzeni dziejów. Jak starałem się wykazać w kolejnych częściach artykułu, hejt stanowił niemal immanentną cechę tej części życia, jaką jest polityka od najdawniejszych czasów, i przez kolejne epoki był stale obecny w życiu publicznym. Współcześnie zaś jego obecność jest zwielokrotniona, na co składa się rosnąca popularność hejterstwa biernego, stosowanego między innymi $\mathrm{w}$ przestrzeni internetowej, a także zjawiska takie, jak marketyzacja świata polityki skłaniająca „czwartą władzę" do korzystania z najniższych pod względem aksjologicznym środków wzbudzenia zainteresowania odbiorcy, w co wlicza się propagowanie wszelkich odmian hejterstwa czy nawet celowe ich wywoływanie.

Niebagatelne znaczenie mowy nienawiści we współczesnym świecie nie może być niezauważane i powinno skłaniać wszystkich badaczy dziedzin społecznych i humanistycznych do podjęcia dalszych wysiłków zmierzających do poszerzania wiedzy o zjawisku, które jest przedmiotem niniejszego artykułu. Konieczne wydaje się więc powstawanie kolejnych artykułów, prac zbiorowych i monografii, bowiem tylko zgłębiając wiedzę o danym zagrożeniu, można odnaleźć skuteczne środki na zapobieganie jego dalszej eskalacji, która niewątpliwie jest faktem.

\section{Bibliografia}

Faryś Janusz (1998), Historia Polski: od 1956 do 1970 roku, Fenix, Poznań.

Głowiński Michał (2009), Nowomowa i ciagi dalsze, Universitas, Kraków.

Język IV Rzeczypospolitej (2010), M. Czerwiński, P. Nowak, R. Przybylska (red.), Wydawnictwo UMCS, Lublin.

Kamińska-Szmaj Irena (2007), Agresja językowa w życiu publicznym, Wydawnictwo Uniwersytetu Wrocławskiego, Wrocław.

Kim Renata, Lis Ewelina (2016), Hejterzy bez zahamowań, „Newsweek”, nr 6/2016. Kryzys migracyjny w UE, największy od II wojny światowej (2015) [w:] Wiadomości.

onet, http://wiadomosci.onet.pl/swiat/kryzys-migracyjny-w-ue-najwiekszy-od-iiwojny-swiatowej/kbxtj7 [dostęp: 08.02.2016].

Lis Tomasz (2006), Polska, głupcze!, Świat Książki, Warszawa. 
Redo Patrycja (2015), Nienawiść do wynajęcia [w:] tvn24.pl, http://www.tvn24.pl/ czarno-na-bialym,42,m/nienawisc-do-wynajecia,543871.html [dostęp: 08.02.2016].

Tkaczewski Dariusz (2010), Mechanizmy wpływu społecznego i manipulacja językowa - czeskie przypadki, Agencja Artystyczna PARA, Katowice.

To oni sa wszystkiemu winni... Język wrogości w polskim dyskursie publicznym (2013), X. Bukowska, B. Markowska (red.), Wydawnictwo Trio, Warszawa.

W świecie internetowych hejterów. W TVN24 opowiadają o „wchodzeniu w zwarcie” (2015) [w:] tvn24.pl, http://www.tvn24.pl/wiadomosci-z-kraju,3/internetowi-hejterzy-czarno-na-bialym,579181.html [dostęp: 08.02.2016].

Wawrzyniak Michał (2015), Hejtoholik, Helion, b.m.w.

Wiśniewska Karolina (2015), Internetowi hejterzy - wszyscy ich mają, lecz nikt o nich nie mówi. Nikt, poza PO, która trolluje sama siebie [w:] na:Temat, http:// natemat.pl/144767, internetowi-hejterzy-wszyscy-je-maja-lecz-nikt-o-nichnie-mowi-nikt-poza-po-ktora-trolluje-sama-siebie [dostęp: 08.02.2016].

\title{
Kamil Durajczyk
}

\section{Hejterstwo w polityce — znak czasów czy odwieczny element gry politycznej?}

\author{
Hate Speech in Politics - a Sign of the Times or an Eternal Part of the \\ Political Game?
}

Słowa kluczowe: hejterstwo, mowa nienawiści, polityka, historia Key words: hating, hate speech, politics, history

\section{Streszczenie}

W artykule autor porusza tematykę mowy nienawiści, odnosząc ją do szerokorozumianej sfery polityki. Dokonuje podziału hejterstwa w obszarze polityki na hejt czynny i bierny. Pierwszy realizowany jest przez osoby aktywnie zaangażowane 
w życie polityczne, a więc polityków. Drugi zaś przejawia się w aktywności społeczeństwa biernie obserwującego i oceniającego życie polityczne, w tym również dziennikarzy oraz komentatorów medialnych. Zasadniczym tłem rozważań jest zaś pytanie czy hejt polityczny istniał od zawsze czy też jest wytworem współczesności.

\begin{abstract}
In the article, the author touches the issue of hate speech and applies it to the sphere of politics. He divides hate speech in the area of politics into active and passive hate. The first one is carried out by people who are actively involved in political life, i.e. politicians. The second, in turn, is manifested by the activity of the society passively observing and evaluating political life, including journalists and media commentators. The primary background for considerations is the question whether political hate has always existed or is a product of modern times.
\end{abstract}

